\title{
FORMATIONS OF THE PERFECT IN THE SABELLIC LANGUAGES WITH THE ITALIC AND INDO-EUROPEAN BACKGROUND*
}

Keywords: Sabellic languages, Oscan-Umbrian verb, perfect

\begin{abstract}
The problem of the origin of the Sabellic perfects (in the older literature called OscanUmbrian) has been discussed at length very often in Indo-European linguistics ever since the $19^{\text {th }}$ century and the monumental work of Robert von Planta (1892-1897). Still, to this very day it remains a mystery. Various hypotheses have been proposed but none of them explained everything clearly and without problems. Especially intriguing is the fact that the multiple formations of the perfect found in Sabellic languages (reduplicated, simple, $-f$-, - $t$ - and - $n k y$-perfects) perform essentially the same function of the preterite tense, being the syncretism of both the Proto-Indo-European aorist and perfect, similarly as in Latin.

In the present article the author seeks to present the compelling hypotheses of the origin of the formations of the perfect in the Sabellic languages, evaluate them according to their supposed probability and present the most probable solution to the problem. The Sabellic perfects are classified into groups and each group is discussed as to its origin and development with the Indo-European background in mind. This is followed by some reconstructions underlying the attested forms. The Sabellic formations treated in this article are the reduplicated perfect, long-vowel perfect, $s$-perfect, simple perfect, $-f$-perfect, $-t t$-perfect, $-k$-perfect, $-n k y$-perfect and the Sabellic future perfect with the characteristic -us- suffix. The discussion is closed by conclusions and the appendix with the complete list of the attested forms of the perfect.
\end{abstract}

* This article is a revised version of the author's M.A. thesis in Classics (Cracow 2009), written under the supervision of Dr. hab. Hubert Wolanin (Cracow). It began as a seminar paper written at Leiden University under the supervision of Dr. Michiel de Vaan (Leiden). I am grateful to both my supervisors for comments and remarks and to Kristen de Joseph (Leiden) for correcting my English. Needless to add, the remaining errors are solely my responsibility. 
The main conclusion of the article is the following: we have generally three tendencies of explaining the origin of the Sabellic perfects: periphrastic, analogical and phonological. The phonological explanation is forceful and therefore not very probable. On the other hand, periphrastic and analogical solutions are extreme and the author thinks that the most probable explanation is the middle solution combining all three approaches.

\section{Introduction}

Ever since the beginning of Indo-European linguistics, the Sabellic languages (or rather Oscan-Umbrian, as it was called then) have been investigated with their better-attested sister language, Latin, in mind. The disproportion in the state of attestation of the Sabellic languages and Latin is enormous, due to the historical developments in ancient Italy in general and the Roman conquest in particular. Analogically, within the Indo-European family, Hittite was considered the main Anatolian language and for some time thought of as the only representative of this group of languages worth researching, while the other languages were almost completely neglected in historical-linguistic research [e.g. in Kronasser's (1956) historical grammar]. Only in recent times has it been shown that the other languages have some important things to say about the overall picture of the Anatolian branch. The same goes for the Sabellic languages, often neglected in research due to the superiority of the Latin material. Yet they can tell us much about the overall linguistic history of the Italic branch (especially the more conservative Oscan language) and provide insights into some of the controversial issues.

One of those controversial issues is the origin of the whole variety of the formations of the perfect in the Italic languages. The Proto-Indo-European perfect essentially had only two distinct formations, an old simple perfect of the type of Greek oĩda and Latin $u \bar{\imath} d \bar{\imath}$ and a reduplicated perfect of the type of Greek mémona, Skt. cakára and Latin meminì. Yet, over time several different formations were created in the history of the Italic branch, and the precise origin of these formations has never been fully and exhaustively explained. This article does not pretend to find the ultimate solution for the aforementioned problem; its major aim is instead to outline the proposed hypotheses and evaluate them according to their probability in the general framework while trying to present new paths toward the solution.

\section{The Italic languages}

The Italic languages, constituting one of the language groups of the Indo-European family of languages, are generally divided into Latino-Faliscan and Sabellic (or Sabellian; in the older literature also Osco-Umbrian ${ }^{1}$ ) group. The Latino-Faliscan subgroup consists of Latin (from 600 вC) and Faliscan (600-150 BC), while the Sabellic

The term "Sabellian" was previously used to denote the minor Italic languages, i.e. all of those apart from Latin, Faliscan, Oscan and Umbrian. Since the decipherment of South Picene in the 1980 s and its establishment as a sister branch of both Oscan and Umbrian, the term "Sabellian" 
consists of Oscan (500-100 вс), Umbrian (400-150 вС) and some minor languages (scantily attested): Paelignian, Marrucinian, Vestinian, Marsian, Aequian, Hernican, Volscian, South Picene (550-350 BC) and Pre-Samnite (500 BC). Within the Sabellic languages the division is made between the Oscan group, the Umbrian group and the Picene group. The Oscan languages are Oscan proper, Paelignian, Marrucinian, Vestinian and Hernican. The Umbrian group consists of: Umbrian proper, Aequian, Marsian and Volscian. Finally, the Picene group comprises South Picene and Pre-Samnite (cf. Wallace 2007: 1-10). Following the scheme of Ringe (2006: 16), the chronological development of the Italic languages would thus be as follows: Proto-Indo-European $>$ North IE (after the separation of Anatolian) $>$ West IE (after the separation of Tocharian) > Italo-Celtic $>$ Proto-Italic $>$ ProtoLatino-Faliscan (Latin, Faliscan), Proto-Sabellic (Oscan, Umbrian, South Picene, Pre-Samnite, etc.). The Sabellic languages use three different scripts: the Latin alphabet, the national Oscan and Umbrian alphabet (derived from Etruscan) and the Greek alphabet.

The position of other languages from within the geographical bounds of Italy (Venetic, Sicel, Etruscan, North Picene, Raetic) is unclear. Etruscan, attested by nearly 6,000 inscriptions, and North Picene are clearly non-Indo-European, along with Raetic, which is probably related to Etruscan. Venetic is an Indo-European language but its genetic affiliation has not been confirmed. Some scholars would count it also as Italic since it shares several important features with this branch (cf. van der Staaij 1995: 193-210).

\section{The Indo-European verb}

The reconstruction of the PIE verb is one of the most controversial topics of contemporary Indo-European linguistics, mostly because of the Anatolian material, especially Hittite. The main problem lies in incorporating the verbal system found in Hittite (with only two tenses - present and preterite - and no optative or subjunctive) with the "Graeco-Aryan" reconstructed model of PIE (based essentially on Vedic Sanskrit and Homeric Greek, with elaborate categories of present, aorist and perfect-stems, three moods, etc.). The tendency seems to favour the hypothesis that Anatolian split off first from the PIE language and attests the older stage of development rather than loss of categories present in Vedic and Greek (cf. Jasanoff 2003, Clackson 2007: 129-151). However, other scholars, most notably the "Erlangen school", seem to favour the traditional explanation (Tichy 2004). For our purposes it is irrelevant whether we consider our point of departure to be West Indo European or the PIE of the German school. It still is essentially the same reconstructed system (the so-called "Cowgill-Rix verb") with three aspect-stems present (denoting imperfective aspect), aorist (denoting perfective aspect) and perfect stem (denoting a sort of stative-resultative aspect).

or "Sabellic" has been used to denote the former and now imprecise (due to the omission of South Picene) term "Oscan-Umbrian". 


\subsection{Proto-Indo-European perfect}

The formation of the perfect stem in PIE follows the pattern of o-graded root in the singular and zero-grade in the plural and e-reduplication. The endings used in the perfect are completely separate from the primary and secondary endings. The basis for such reconstruction of the perfect are the perfect stems of Homeric Greek and Vedic Sanskrit. The endings of the perfect are the basis of the Hittite hi-conjugation - a conjugation of the present found in Hittite with the endings essentially continuing the PIE perfect - in contrast to the mi-conjugation, which continues the PIE athematic present. The explanation of the development of the Hittite $h i$-conjugation still remains controversial (cf. Jasanoff 2003 for a new hypothesis on the topic).

\subsection{Indo-Iranian perfect}

In Vedic Sanskrit, the oldest language of the Indic branch, the perfect is made with reduplication and still very frequently has the stative meaning as inherited from PIE (Fortson 2004: 192). Examples of Vedic forms are cakára 'make,' tutóda 'strike,' dadháu 'place' or véda 'know' (Burrow 2001: 341-346). In Avestan, the other oldest member of the Iranian branch, the perfect is also still clearly visible: vaèd 'a 'know'.

\subsection{Greek perfect}

In Greek, the PIE perfect is still visible in Homeric Greek, frequently with stative meaning. There is only one attested personal form of the perfect tense from the Mycenaean period: e-pi-de-da-to PY Vn 20.1 /epidedastoy/ '(he, she, it) distributed' (Sowa 1998: 292). Even in the language of the Greek inscriptions,

the perfect expresses a past event and its continuing consequences, while the aorist expresses the event and leaves the consequences to be inferred (Ringe 1984: 533).

\subsection{Latin perfect}

In Latin the PIE perfect and aorist merged into one category of the past perfective tense. Remnants of the old stative meaning are visible in forms like odi 'I hate', memini' 'I remember' and noū 'I know'. The remnants of the PIE aorists are visible in the following Latin forms (after Safarewicz 1953: 216-217 and Kümmel 2007: 28-29): fui , continuing ${ }^{*} \mathrm{~b}^{\mathrm{h}} \overline{\mathrm{u}}(\mathrm{w})$-ed, i.e. the reanalyzed PIE root aorist ${ }^{*} \mathrm{e}-\mathrm{b}^{\mathrm{h}} \mathrm{uh}_{2}-\mathrm{t}$ (cf. Greek éphun, Skt. ábhīt), cecidī, continuing the reduplicated aorist (cf. Greek kekádonto), fècī, continuing the root aorist with $k$-suffix ${ }^{2}{ }^{*} \mathrm{~d}^{\mathrm{h}} \mathrm{eh}_{1}-\mathrm{k}$ - (cf. Greek éthēka); and $d \bar{i} x \bar{i}$, continuing ${ }^{\star}$ deik-s-ai, i.e. the reanalyzed form of the PIE sigmatic aorist *e-dēik-s-m (cf. Greek édeiksa, Avestan dāiš). On the other hand, the PIE perfect is

2 That is, an independent formation or just root aorist with - $k$ - suffix giving the synchronic long-vowel - $k$-perfect. The origin of the formations with $-k$ - suffix present in Latin, Greek and Phrygian is dubious (Meiser 2003: 199-200). 
continued in Latin in forms such as $u \bar{\imath} d \bar{\imath}$, from * ${ }^{*}$ oidh $_{2}$ ei (cf. Greek oĩda, Skt. véda), or meminī, from PIE ${ }^{\star}$ me-mon- $\mathrm{h}_{2} \mathrm{ei}$ (cf. Greek mémona). The synchronic long-vowel perfect in Latin goes back partly to the PIE reduplicated perfect with roots in the first laryngeal (so perfect $\bar{e} d-<{ }^{*} \mathrm{~h}_{1} \mathrm{e}-\mathrm{h}_{1} \mathrm{~d}$ - to the present $\breve{e} d \overline{\text { and }}$ then $u \bar{e} n$ - to uĕniō analogically), and partly to the ablauting PIE root aorist ending in laryngeals ( $f \bar{e} c-<$ ${ }^{*} \mathrm{~d}^{\mathrm{h}} \mathrm{eh}{ }_{1} \mathrm{k}$ - to the present $f \breve{a} c i \bar{o}<{ }^{*} \mathrm{~d}^{\mathrm{h}} \mathrm{h}_{1} \mathrm{k}$-yō and then $c \bar{e} p$ - to căpiō analogically). There is also a typically inner-Latin formation of the perfect, the so-called $u$-perfect like in portāui 'I carried', nēuì 'I sewed' or audīu ' 'I heard'. There are generally three hypotheses concerning the origin of this formation:

some have tried to connect it with the $-u$ in Sanskrit perfects like Ved. dadáu 'I/he gave' (root $d \bar{a}-$ ), tastháu 'I stood' (root sthā-); others have preferred to say that the pattern began with a verb whose perfect stem could have originally ended in *-Vw-, such as perhaps gnōuī ‘I knew’ ( ${ }^{\star} \mathrm{g} n \mathrm{~h}_{3} \mathrm{~W}-$ ) (Fortson 2004: 256-257).

Recently, Seldeslachts (2001) published an extensive monograph on the origin of the Latin perfect. The newest treatment of the Latin perfect formation is the work of Meiser (2003). Meiser essentially follows a third hypothesis, established by Helmut Rix (1992), that posits a periphrastic origin for Latin $u$-perfect. Rix argues that the Latin $u$-perfect has its origin in the periphrasis of the perfect participle active and the form of 'to be' est. He traces it to * portāwos est which is in turn simplified into * portāwist and gives the attested Latin portāvit (Rix 1992: 229-233). As we shall see later, same kind of analysis is employed by Rix when dealing with the Sabellic formations of the perfect.

\section{Sabellic perfect}

The main problem which the current article investigates is concerned with the formation of the perfect stem in the Sabellic languages and its origin. It is generally assumed that the PIE aorist and perfect merged in Proto-Italic. However, the complete merger must have occurred after the separation of Latino-Faliscan and Sabellic languages, as we find different types of perfect stem formation which are exclusive to Latin, Oscan or Umbrian, respectively, and also different endings in Latino-Faliscan and in Sabellic (cf. Rix 2003a: "aorist and perfect were still distinct in P[roto]It[alic], even if their signification became more similar to each other"). In Latin, the endings of the perfect continue the PIE perfect endings (with different contaminations), whereas in Sabellic they continue the secondary aorist PIE endings (thematic aorist endings, according to Rix 2003a: 15). Moreover, we find differences in the creation of perfect subjunctive, which in Latin is created by means of the suffix $-\bar{\imath}$ - and in Sabellic by $-\bar{e}-$, and in the future perfect, which in Latin is signalled by -er-<-is- and in Sabellic by -us- (Meiser 2003: 32). There are more or less (depending on differences in classification among scholars) nine different types of perfect stem formation in the Italic languages: reduplicated, with long stem vowel, simple, $s$-perfect, $k$-perfect, $u$-perfect, $f$-perfect, $t t$-perfect and $n k y$-perfect. The latter 
three ( $f$-perfect, $t t$-perfect and $n k y$-perfect) are exclusive to Sabellic languages, the $t$ t-perfect exclusive to Oscan (and minor languages related to Oscan) and the $n k y$-perfect exclusive to Umbrian. On the contrary, the $u$-perfect is present only in Latin and the same might account for the s-perfect, as the forms pointing to its existence in Sabellic are scanty and dubious. Although the matter of the origin of such a varied scope of different perfect formations in Sabellic was touched upon quite often (Osthoff 1884: 191-263, von Planta 1892-1897: 326-401, Brugmann 1893: 1234-1245, Sommer 1926, Olzscha 1958, Diels 1959, Olzscha 1963, and Markey 1985, among others), no complete answer has ever been given. It is especially worth noting that "there is essentially no adequate explanation of the multiplicity of forms alongside their presumed uniformity of function" (Silvestri 1998).

The present article does not claim to find an ultimate solution to the problem mentioned above. As has been already observed,

Due first of all to the limited number of inscriptions we have in Sabellic and second to their inconsistent spelling, any sketch of Sabellic phonology, both historical and synchronic, must be tentative (Fortson 2004: 264).

Obviously, the same also goes for morphology. It is then the general aim to investigate in detail the attested perfect formations and the proposed hypotheses concerning their origin, with an evaluation of their plausibility. As regards evaluation of the plausibility of the hypotheses, I follow Ringe (1990: 221) in stating that irregular sound change is less plausible than a regular one; between two regular but incompatible sound changes phonetic plausibility should give us the answer, and in terms of reckoning with analogical change,

it must be judged in the specific context of the paradigm in which it is supposed to have taken place; and in order to render such judgements possible, that paradigm, as well as other relevant paradigms in the language, must be reconstructed in the greatest possible detail (Ringe 1990: 221).

It should be noted, however, that as in many other cases in Indo-European linguistics, the complete answer to the question of the origin of the Sabellic perfects may be hidden in the depths of the irretrievable and forgotten past, and we must also be prepared to accept this fact rather than multiply the hypotheses based on dubious evidence. In the author's opinion, facta non sunt multiplicanda, and therefore we should not present other theories of probable origin of these formations unless we gather a clear evidence in support of such claims.

What follows is the classification of the attested perfects with the proposed reconstruction. Every class is closed with some general remarks as to the proposed hypotheses concerning its origin and its evaluation. The division of the formations of the perfect in classes is made on diachronic-synchronic terms, that is, the analysis is neither completely diachronic nor completely synchronic. It follows the custom present in Indo-European linguistics to analyze the form basically according to its origin, while keeping in mind its synchronic stance. If we were to analyze the forms synchronically, only some of the original reduplicated perfects should be classified 
as simple perfects and several other specific classes should be postulated. Besides, we are unable to tell how the speakers of the language perceived the forms. Pure diachronic analysis again would imply the non-existence of the - $t t$-perfect, $-f$-perfect and - nky-perfect, as those forms are clearly inner-Sabellic developments.

\subsection{Reduplicated perfect}

This formation originally goes back to PIE, where it was a typical pattern of perfect formation, that is, $e$-reduplication, $o$-grade of the root and stative aspect (at least for West Indo European, i.e. after the separation of the Anatolian branch and possibly also Tocharian), e.g. * ste-stoh ${ }_{2}-\mathrm{h}_{2} \mathrm{e}$ 'I am standing'; cf. Gk. gégona, mémona, Skt. cakára, etc.

The reduplication syllable was uniformly $* / e /$, and it was preserved as such in Sabellic (e.g. O. deded 'dedit', U. dirsust [<*dedust], O.fefacid 'fecerit', U. peperscust 'posuerit'), but assimilated in Latin to the vowel of the root if it was /i/, /o/ or /u/ (e.g. momordī, cucurrī for earlier memordī, cecurrī but pepulī [Buck 1904: 170]). The Oscan form fifikus 'feceris / fixeris' with /i/ in the reduplication syllable may appear to be a trace of a similar phenomenon in Sabellic to some (Buck 1904: 170), and even enough evidence for others to claim that the "colouring of the reduplicated syllable probably took place independently in the Italic languages" (van der Staaij 1995: 164). As we have only one form attested, I find such hypotheses highly speculative. After all, "it would be imprudent to try to develop any theories about the vocalism of a hapax legomenon for which there is no obvious explanation" (Cowgill 1957: 108). As to the root syllable there is, as van der Staaij (1995: 164) correctly observes, no trace of original PIE ablaut, i.e. $o$-grade in singular and zero-grade in plural, e.g. O. deded 3 sg., O. dedens 3 pl., U. dersicust 3 sg., U. dersicurent 3 pl.

There is no unanimity whether the forms like O. aamanaffed 'mandavit', O. prúffed 'probavit' or O. fufens 'fuerunt' should be classified as reduplicated perfects according to their probable origin [so Buck (1904: 170) and others claim for the first two forms; von Planta (1892-1897: 330-331) on O. fufens: "schwerlich starkes reduplicirtes Perfect") or as $f$-perfects (van der Staaij 1995: 169)]. The forms synchronically have /f/ phonemes and therefore might be seen as $f$-perfects, though their origin is different. They will be discussed in the section devoted to $f$-perfects (see 4.5. below).

The following reconstructions illustrate the origin of some of the Sabellic reduplicated perfects presenting the general pattern (cf. van der Staaij 1995: 164, Meiser 2003: 158-166):

O. deded $<{ }^{*}$ de-dh ${ }_{3}$-ed (root ${ }^{*} \mathrm{deh}_{3^{-}}$'to give')

This form has the generalized zero-grade instead of the expected full grade in the root. The respective $3 \mathrm{pl}$. form is found in the $\mathrm{O}$. dedens.

O. dadid / dādīd/ $<{ }^{*}$ dād + dedid $<*$ de- $\mathrm{dh}_{3}-\mathrm{ih}_{1}-\mathrm{t}$

This form consists of the preverb $d \bar{a} d$ and the reduplicated perfect subjunctive reconstructed as the zero-grade ${ }^{*}$-ih ${ }_{1}$ - suffix. The reduplication syllable is in turn syncopated. 
O. fifikus $<{ }^{*}$ fi-fig-us $<{ }^{*} \mathrm{~d}^{\mathrm{h}} \mathrm{e}-\mathrm{d}^{\mathrm{h}} \mathrm{ig}^{\mathrm{h}}-\left(\mathrm{b}^{\mathrm{h}}\right) \mathrm{us}(\mathrm{t})$ (root ${ }^{*} \mathrm{~d}^{\mathrm{h}} \mathrm{eig}{ }^{\mathrm{h}}$ - 'to form')

This form shows an irregularity in the reduplication vowel. It may have been assimilated to the root vowel which was itself generalized from the full grade to the zero-grade. The future perfect suffix -us- (see 4.9. below) probably goes back to the univerbation of the participle and the future of the verb "to be" fust.

U. dersicust $<{ }^{\star}$ dedikust $<{ }^{\star}$ de-dik- $\left(\mathrm{b}^{\mathrm{h}}\right) \mathrm{us}(\mathrm{t})-\mathrm{t}$ (root ${ }^{\star}$ deik- 'to show')

This form shows a typical perfect reduplication and the generalized zero-grade in the root. The intervocalic $* / d$ / is changed to the typical Umbrian sound /řl, written as $\langle\mathrm{rs}\rangle$ in the Latin alphabet. The future perfect suffix - us-is followed by the ending of $3 \mathrm{sg}$. The respective $3 \mathrm{pl}$. form is attested as Umbrian dersicurent.

Generally, this type of perfect is the least controversial. It stems from both the PIE perfect and the PIE reduplicated aorist.

\subsection{Long-vowel perfect}

This formation goes back partly to the PIE aorist (Lat. fēe $\bar{\imath}<{ }^{*} \mathrm{~d}^{\mathrm{h}} \mathrm{eh}-\hat{\mathrm{k}}-\mathrm{h}_{2} \mathrm{ei}, \mathrm{O} . h i$ pust $\left.<{ }^{\star} \mathrm{g}^{\mathrm{h}} \mathrm{eh}_{1} \mathrm{~b}^{\mathrm{h}}-\right)$ partly to the long-vowel preterites, whose status in PIE is unclear (Cowgill 1957, Pike 2003), and partly to the PIE reduplicated perfect (Lat. fūg $\bar{\imath}<$

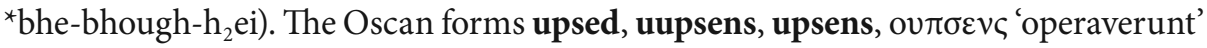
are classified by some as $s$-perfects (Wallace 2007: 29), which seems improbable to me as the non-perfective gerundival form úpsannam 'operandum' also contains /s/. Others (van der Staaij 1995: 165) consider them to be reduplicated perfects ( $\left.{ }^{*} \mathrm{He}-\mathrm{Hop}-\right)$ in origin. The fact is that we have /ō/ in the perfect and / $\breve{\mathrm{o}} /$ in the present. Whether this is the result of morphological vowel lengthening or reduplication is impossible to tell. The forms of hipid / hēpēd/ 'habuerit' as compared to the present hafiest with short vowel basically follow the same pattern.

The following reconstructions illustrate the origin of some of the Sabellic longvowel perfects presenting the general pattern: (cf. van der Staaij 1995: 165, Meiser 2003: 153-157)

O. uupsens $<{ }^{\star}$ ōps- lengthened morphologically $<{ }^{\star} h_{3}$ ep-s- (root ${ }^{\star} h_{3}$ ep-) 'to work' or from $<{ }^{\star}$ ops- $<{ }^{\star} \mathrm{He}-\mathrm{Hop}-\mathrm{s}-<{ }^{\star} \mathrm{He}-\mathrm{h}_{3}$ ep-s-

As mentioned above, we are not able to tell whether the form is reduplicated or morphologically lengthened in origin. It seems, however, that this verb is denominal. Firstly, the Proto-Italic noun *opes 'work' was created (cf. Latin opus) from the PIE root ${ }^{\star} h_{3}$ ep- 'to produce, to work.' This noun formed the denominal present *opesāye- [cf. Latin operāri (De Vaan 2008: 432)], from which the present stem *ops-, with syncope of the internal /e/, was abstracted, and used either with reduplication or lengthening to form the Oscan perfect uupsens.

O. hipid < (cont.) ${ }^{\star} \mathrm{h}_{1} \mathrm{e} \mathrm{p}-\mathrm{ih} \mathrm{h}_{1} \mathrm{t}<{ }^{\star} \mathrm{h}_{1} \mathrm{e}-\mathrm{h}_{1} \mathrm{op} / \mathrm{h}_{1} \mathrm{p}-\mathrm{ih} \mathrm{h}_{1} \mathrm{t}$ (root ${ }^{\star} \mathrm{h}_{1} \mathrm{ep}-$ 'to catch, to have') This form has been partly contaminated by the form hafiest 'habebit' (the Oscan stem haf- from PIE ${ }^{*} \mathrm{~g}^{\mathrm{h}} \mathrm{Hb}^{\mathrm{h}}$-; cf. Latin habeo $<{ }^{\star} \mathrm{g}^{\mathrm{h}} \mathrm{Hb}^{\mathrm{h}}-\mathrm{h}_{1} \mathrm{ye}$ ?, De Vaan 2008: 277-278), from which the $/ \mathrm{h} /$ in anlaut has been taken over. The root vowel is 
lengthened either through morphological lengthening or reduplication. The case is the same with the Oscan future perfect form hipust.

\section{3. -s-perfect}

Originally, this formation most probably goes back to the PIE sigmatic aorist. In Latin it may be represented by forms like dìxī (cf. Gk. édeiksa) and also by futures of the type faxo. In Sabellic, the status of this formation is dubious. Two forms point to this type of perfect: Pael. lexe and U. sesust 'sederit'. According to Wallace (2007: 29), O. upsed 'operavit' should also be classified as an s-perfect, though I prefer different a classification [see 4.2. above; compare also von Planta (1892-1897: 338)]. As for Paelignian lexe, it may well be a simple present formation as compared to Latin legistis (Silvestri 1998: 338). The interpretation is controversial. The U. sesust form has been analyzed as going back to the participial stem in sesso- (Buck 1904: 170). A different analysis is postulated by Rix (2003a: 16):

the sigmatic aorist disappeared in Sabellian, two isolated, especially motivated stems excepted: sess- <* sed-s- 'sit' (Umb. sesust) can be understood as a reduplicated perfect, and ${ }^{\star o p}$-s- 'produce' (Osc. uupsens) was supported by the suppletive present ope-sā-

Additionally, it must be observed that the absence of this very productive type of aorist in Sabellic, which underlies the very frequent $s$-perfects in Latin, is rather odd.

The attestation of the Paelignian form is as follows:

P. lexe Ve. 213,7 / Pg 9 (Corfinium) 2 pl. pr.?

The probable reconstructions of the two forms are:

P. lexe $<{ }^{\star}$ leg-e-se (Meiser 2003) or ${ }^{\star}$ leg-s-te or ${ }^{\star}$ leg-is-te

U. sesust $<{ }^{*}$ se-sd-us-e-t or $<{ }^{*}$ sed-us-e-t

Both examples of the probable Sabellic s-perfect are dubious, and therefore the existence of this formation in Sabellic should rather be rejected (cf. van der Staaij 1995: 166).

\subsection{Simple perfect}

The simple perfect (i.e. without reduplication) may go back to the PIE aorist (root, thematic), or may have lost its perfect marker due to the analogy to with the present stem (van der Staaij 1995: 167). The examples of the loss of the reduplication are: $\mathrm{O}$. dicust to the reduplicated U. dersicust; U. fakust 'fecerit' to the reduplicated O. fefacid (though the examples are drawn from different languages). Other examples of this class are O. kúmbened 'convenit', O. cebnust, U. benust 'venerit' and

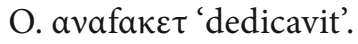

The following reconstructions illustrate the origin of some of the Sabellic simple perfects presenting the general pattern: (cf. van der Staaij 1995: 167, Meiser 2003: 209) 
O. kúmbened < ${ }^{\star}$ kom-gwem-ed (root ${ }^{\star} \mathrm{g}^{\mathrm{w}} \mathrm{em}$ 'to go')

This form presents the outcome of the root of the verb 'to go', widely attested within the Indo-European languages (cf. Greek bainō and Latin věniō from the zero-grade $\left.{ }^{*} g^{w} m-y o\right)$. The nasal vowel is changed to $/ \mathrm{n} /$ as in the other languages. Particularly interesting is the behaviour of the PIE labiovelars, which turn into labials in Sabellic.

U. benust $<{ }^{*} \mathrm{~g}^{\mathrm{w}} \mathrm{em}-\left(\mathrm{b}^{\mathrm{h}}\right) \mathrm{us}-\mathrm{t}$

This form again represents the same root as above with the same sound development. The only difference is that it is attested in Umbrian and that it is the future perfect with the characteristic -us- suffix. The case is the same with the Oscan cebnust, where we have the preverb ce- and the form with syncope of internal /e/.

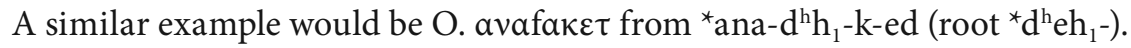

We should also mention that in the older literature, the Sabellic l-perfect was postulated. The issue has been solved by Meiser in 1986.

The Umbrian forms entelust, apelust which were formerly taken as $l$-perfect forms of ententu, ampentu, have turned out to be future perfect forms built from root aorists from roots in $-l$. The underlying roots of these verbs are probably ${ }^{*}$ telh $_{2}$ - 'carry', cf. Latin tollere, and ${ }^{*}$ pelh $_{2^{-}}$'beat', cf. Latin pellere, respectively. ententu, ampentu, then, reflect * ${ }^{*}$-tel-n- $\mathrm{h}_{2}$-tōd, ${ }^{*}$ pel-n- $\mathrm{h}_{2}$-tōd, respectively, with a development *-ln- > ${ }^{*}$-nn- > -n-. (van der Staaij 1995: 171 summarising Meiser 1986: 164).

Mention must also be made of the so-called 'thematic perfect.' Forms such as Oscan manafum or South Picene ad-staíúh and opsút are sometimes classified as thematic because of their supposed thematization (thus van der Staaij 1995: 165). The ending of the former would come to the thematic aorist ${ }^{*} \mathrm{o}-\mathrm{m}$, while that of the latter is sometimes interpreted as the alleged $\bar{o}$-perfect of South Picene (for details, see Adiego Lajara 1992: 121).

\section{5. $-f$-perfect}

This formation is absent from Latino-Faliscan but present exclusively in Sabellic languages. Its origins are disputed. According to Rix (1992: 239), the source of this $-f$-is the reduplicated perfect stem, whether ${ }^{\star}$ fef- $<{ }^{\star} \mathrm{d}^{\mathrm{h}} \mathrm{ed}^{\mathrm{h}} \mathrm{h}_{1^{-}}$(as in prúffed) or fuf- $<$ ${ }^{*}$ fefw- $<{ }^{*} \mathrm{~b}^{\mathrm{h}} \mathrm{eb}^{\mathrm{h}} \mathrm{w}$ - (as in fufens). The same analysis is posited by Buck (1904: 172), though he classifies aamanaffed and prúffed as reduplicated perfects (see 4.1. above). The competing hypothesis of Hamp (1990), who traces the origin of this formation to the rounded laryngeal ${ }^{\star} \mathrm{x}^{\mathrm{w}}$, does not seem very plausible. Rix traces the origin of the reduplication itself to the univerbation of the periphrasis, explaining e.g. Oscan staieffud as going back to the construction of the present participle * staients and the perfect ${ }^{\star}$ fefud $<{ }^{*}$ steh ${ }_{2}$-yeh ${ }_{2}$-nt-s $+{ }^{\star} b^{\mathrm{h}} e-b^{\mathrm{h}} u H-t$.

Recently, three new forms of the reduplicated perfect were found in the socalled Tortora inscription. The forms belong to the archaic Pre-Samnite dialect of the South Picene group of the Sabellic languages. Of those the most important 
is the Pre-Samnite form fvfvFod, analyzed as /fufuwond/ (Beckwith 2008), which shows the Italic perfect paradigm of the verb 'to be' with the thematization of the older ${ }^{\star}$ fufuwēr (Beckwith ibid.).

The following reconstructions illustrate the origin of some of the Sabellic $f$-perfects presenting the general pattern (cf. van der Staaij 1995: 169-170):

O. manafum $<{ }^{*}$ man-fe-fom $<{ }^{*}$ man- $\mathrm{d}^{\mathrm{h}} \mathrm{e}-\mathrm{d}^{\mathrm{h}} \mathrm{h}_{1}-\mathrm{O}-\mathrm{m}$

This form is probably a thematization of the original form (see 4.4. above for the thematic perfect classification). Observe also the Latin counterpart mandāre which is, as in Oscan, the compound of manus + dāre 'to put at hands.' O. aamanaffed is the same root only with a preverb aa- and with double -ff- reflecting earlier ${ }^{*}$ a-man-fefed and ${ }^{*}$ a-man- $d^{\text {he }}$ - $d^{\text {h }} h_{1}$-ed.

O. fufens $<{ }^{*} b^{\mathrm{h}} e-b^{\mathrm{h}}$ woh $_{2} / \mathrm{b}^{\mathrm{h}} \mathrm{uh}_{2}$ -

This word attests the Sabellic form of the perfect of the verb 'to be.' It is possible that this form has been reanalyzed and its /f/ element used as a marker of the perfect. The Pre-Samnite form $f v f v F o \delta$ with the -ond ending is a thematization of the earlier 3. pl. perfect ending ${ }^{*}$-èr.

O. aíkdafed $<{ }^{\star} h_{2}$ eyk-dā- $d^{h} h_{1}$-ed or from Proto-Italic ${ }^{*}$ aikidans fufed (WOU 2000: 68)

O. prúffed $<{ }^{*}$ pro-fefed $<{ }^{*}$ pro- $\mathrm{d}^{\mathrm{h}} \mathrm{e}-\mathrm{d}^{\mathrm{h}} \mathrm{eh} \mathrm{h}_{1}-\mathrm{d}$

U. andirsafust $<{ }^{*}$ andi-daf fust $<{ }^{*}$ am-di-da-nt-s fust

\section{5. -tt-perfect}

This formation is only present in Oscan and some minor Sabellic languages related to Oscan (Paelignian, Volscian, Marrucinian). The inscriptions with $t$-perfect attestations come mainly from the $2^{\text {nd }}$ century $\mathrm{BC}$ and from the places of Pietrabbondante $(\times 6)$, Pompeii (×7) and Rossano (×4). According to some (Buck 1904: 172, Rix 1992: 238), it is based on the periphrastic construction with a to-participle and a past form of the verb 'to do,' e.g. *termnātom fefakom [theoretical ${ }^{\star} \mathrm{CeC}$-ā-to- $\mathrm{d}^{\mathrm{h}} \mathrm{h}_{1}$ - as in van der Staaij (1995: 170)]. In Oscan it is only present in $\bar{a}$-stems. Several other hypotheses have been developed to explain the origin of this formation (see von Planta 1892-1897: 342-348 for a good survey), including the change of ${ }^{\star} k y>t t$ as in Greek and the connection of the Oscan $t$-perfects to the Umbrian $n k y$-perfects and Latin $u$-perfects (Saint John 1973a), which is a very forceful hypothesis. It seems that even more modern theories (e.g. the one mentioned above by Saint John 1973a) go back to the ones already posited long ago (von Planta 1892-1897: 347-348). The Volscian sistiatiens form has been investigated several times (cf. Wallace 1985) and still remains a problem.

Recently, however, Beckwith (2005), criticizing Rix’s (1992, 2003a, 2003b) periphrastic explanations for lack of economy, has come out with an analogical explanation (or rather a series of analogical extensions and reanalyzes). He creates a proportion ${ }^{\star}$ sista- (pres.): ${ }^{\star}$ sistatt- (perf.) $={ }^{\star}$ dōnā- (pres.): $\mathrm{X}$ (perf.), $\mathrm{X}={ }^{\star}$ dōnā-tt, where the $-t t$ - element has been reanalyzed as a perfect marker by the speakers. And although the more or less contemporary date of the attested $t t$-perfects could in principle point to an analogical explanation, the sound change of ${ }^{*} \mathrm{twV}>{ }^{*} \mathrm{ttV}$ that he assumes is not without difficulties (cf. Buck 1904: 172). 
The following reconstructions illustrate the origin of some of the Sabellic $t$-perfects presenting the general pattern: (cf. van der Staaij 1995: 170)

O. dadikatted $<{ }^{*}$ dat-dikā-tt-ed

This form is a complete rendering of the Latin dedicauit perfect. It is attested from an inscription dating back to the end of the $2^{\text {nd }}$ century $\mathrm{BC}$.

duunated $<{ }^{*}$ dōnā-t-ed $<{ }^{*} \operatorname{deh}_{3}$-no- (or periphrasis with ${ }^{\star}$ duunatom fefakom)

famatted $<{ }^{*}$ fāmā-tt-ed $<{ }^{*} \mathrm{~b}^{\mathrm{h}} \mathrm{eh}_{2}-\mathrm{meh}_{2}-$

prufatted $<{ }^{*}$ profā-tt-ed $<{ }^{*}$ prob $^{\text {h}}$ -

seganatted $<{ }^{\star}$ sek-na-

teremnattens $<{ }^{*}$ teremna-/termen-ā-tt-ēr(i)

tribarakattins $<{ }^{*}$ trēb-ark-ā-t-ē-nd (Rix 2003a: 18) (denominative verb)

tribarakattuset $<{ }^{*}$ trēb-ark-a-tt-us-ed $<{ }^{*}$ trēb- $\mathrm{h}_{2}$ erk-

M. amatens $<{ }^{\star} \mathrm{h}_{2} \mathrm{emh}_{3^{-}}\left(\mathrm{LIV}^{2} 2001: 266\right)$

\section{7. - - -perfect}

This formation is scarcely attested in the Sabellic languages. It is possible that it can be compared to the $-k$ - suffixes present in Latin, cf. féc $\bar{\imath}<{ }^{*} \mathrm{~d}^{\mathrm{h}} \mathrm{eh}-\hat{\mathrm{k}}-\mathrm{h}_{2} \mathrm{ei}$, and to the $k$-perfects present in Greek, e.g. héstaka. The etymology of this $-k$ - both in Sabellic and in Latin and Greek still remains a mystery (Meiser 2003: 199-200, van der Staaij 1995: 171).

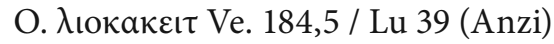

O. kellaked Pocc. 14,15 / Sa 10,12 (Pietrabbondante) 3 sg. pf.

\section{8. $-n k y$-perfect}

The $n k y$-perfect formation is exclusive to Umbrian and appears in the future perfect forms. Rix (1992) [building on the idea of Sommer (1926)] traces its origin to a univerbation of the instrumental of an $\bar{a}$-stem with a preterite of the $i$-present of the root ${ }^{*} \mathrm{~h}_{1}$ nek- 'to bring', which gives Umbrian *ankie/o-. Poultney (1959: 135) traces the origin of these perfects to "a combination of an accusative noun in -am, -im + ${ }^{*} k e+i u s t$ and other forms of the perfect system of the verb 'go'” The hypothesis of Saint John (1973a), connecting the Oscan $f$-, Umbrian $n k y$ - and Latin $u$-perfects, has already been mentioned and refuted above. The periphrastic theory of Jerrett (1974) is less convincing than the one by Rix (1992), as he comes up with an IE root *kei unattested in Sabellic.

The following reconstructions illustrate the origin of some of the Sabellic nkyperfects presenting the general pattern:

U. purdinşiust < ${ }^{*}$ por-d(o)uh ${ }_{3}$-nky-us-t (van der Staaij 1995: 171)

U. combifianşiust < ${ }^{*}$ kom- $\beta$ ißiiā-nkyom $<-$ b $^{\text {hid }}{ }^{\text {hiiām }} \mathrm{h}_{1}$ nkyom (Rix 2003b: 158)

\subsection{Future perfect}

It is characteristic for the Sabellic languages to form the future perfect stem with the -us- suffix. Examples of this formation are numerous. 
Rix (1992) traces the origin of this suffix to another periphrastic construction - the active perfect participle and the future of the auxiliary verb 'to be,' e.g. ${ }^{*} \mathrm{~g}^{\mathrm{w}}$ eg ${ }^{\mathrm{w}}$ en-wos $\mathrm{b}^{\mathrm{h}}$ usti $>{ }^{*}$ bebenwos fust $>{ }^{*}$-wos fust $>{ }^{*}$-usfust $>-$ ust. The traditional explanation is given by Buck (1904: 173) and Poultney (1959: 136), who assume that the -us- suffix has been taken analogically from the Sabellic future form of the verb 'to be,' i.e. fust. This solution is in turn criticized by Saint John (1973b), who postulates a $u$-perfect in Sabellic [an idea also mentioned by von Planta (1892-1897)]. This idea in turn is criticized by Xodorkovskaya (1993), who suggests that the suffix is a combination of two formants: the ${ }^{*}$ - $u$ - and ${ }^{*}$-s-. Recently, Jasanoff also proposed the same explanation, adding some arguments for the similar analogical spread of the Latin -is- preterital suffix (Jasanoff 1987; similarly, Jasanoff 1991: 86). The exact origin of this suffix remains unknown. It has also been postulated earlier that the -us- suffix might be related to the Latin $u$-perfect (von Planta 1892-1897: 373) or the PIE perfect participle in *-wos-/-wes-/-us- (Schultze 1887: 272-274). The theory of the participial origin has been also taken over by Pulgram (1978: 117). He traces -us- back to the nominative singular of an

ancient active perfect participle in -us- which has been provided with the regular inflexional endings: 2 sg. -us-ses, 3 sg. -us-set, from which later, by syncope, -us(s), -ust, and 3 pl. -us-sent, whence Oscan -uset, -uzet, Umbrian -urent (Pulgram 1978: ibid.).

The following reconstructions illustrate the origin of some of the Sabellic future perfects with the characteristic -us- suffix presenting the general pattern:

U. dersicurent $<{ }^{*}$ dedikus fusent $<{ }^{*}$ dedik-wos fus-ent (Rix 2003a: 20)

U. portust $<{ }^{*}$ portus fust $<{ }^{*}$ port-wos fust (Rix 2003a: 20)

O. tribarakattuset $<{ }^{*}$ trēb-ark-ā-t-us-ed $<{ }^{*}$ trēb-ark-ā-t-wos fust

All of the analyzed forms are in origin univerbations of an active perfect participle in *-wos- and the future of the verb 'to be' -fust. The double /tt/ in the Oscan form is explained by Rix as an optional littera-rule by means of which the "long /ā/ plus single /t/ became short/a/ plus geminated /t/ (...) V:K -> VKK” (Rix 2003a: 20).

\section{Conclusions}

From what has been shown it follows that there are generally three tendencies of explaining the divergent Sabellic formations of the perfect in today's Indo-European linguistics. The first tendency would be to explain the forms by periphrasis. Postulated initially by Buck and Sommer, this hypothesis is nowadays identified with Rix and Meiser. The second option would be to explain the different perfects as originating from single forms and then expanded to the other forms analogically. This hypothesis is now identified with Beckwith's 2005 article. The third option would be the explanation posited by Jack Saint John whereby all of the divergent perfect formations (including the Latin $u$-perfect) are explained in a single theory, though very forceful and therefore not convincing. 
If the third hypothesis is not very probable, the first one is also not without problems. Exhaustive criticism is voiced by Beckwith (2005: 148):

this would require that proto-Italic had at least three different isofunctional periphrastic formations to yield the attested forms: one to generate the Latin $-v$-perfect, one for the Oscan - $t$-perfect, and one for the Umbrian ${ }^{*}-n k y$-perfect. Worse, these three formations would have to be radically different from one another: an active perfect participle ${ }^{*}$ portāwos est for the Latin formation, but a past passive participle with ${ }^{\star}$ fefakom for the Oscan along with another formation for the Umbrian (...), and yet these divergent formations would have exactly the same function.

On the other hand, Beckwith's analogical explanation has problems with the sound development of ${ }^{*} \mathrm{tw}>t t$, and in the fact that analogy requires an explicit motive, which we are not always able to observe, and a model on which to operate.

It is also worthwhile to observe that the respective Sabellic counterparts of the Latin perfects have either $t t$-perfect forms or $f$-perfect so prúffed: posuit, prúfatted: probauit, manafum: mandaui, dadíkatted: dedicauit. The Latin always has its $u$-perfect here as counterpart.

In my opinion, neither of the extreme theories, as I would call them, that trace the origin of the perfect formations only to periphrasis (Rix) or only to analogy (Beckwith) is correct. We do not normally observe such strict operations of either analogy or periphrasis within the languages and we have to keep in mind that the Sabellic languages are actual attested languages of the specific region and specific time. They are not our models of reconstructed, hypothetical proto-languages.

And even within our reconstructed languages we should remember that we are actually unearthing a system and not hundreds of unattached elements:

(...) we view Proto-Indo-European as a language, from which the attested IndoEuropean languages have developed, and not as a storehouse of roots, stems and affixes from which the speakers of the various languages were free to select what they wanted, like children playing with building blocks (Cowgill 1973: 273).

Keeping that in mind, the middle solution might prove to be correct: namely, that the divergent Sabellic perfects are just the effect of regular sound changes within the attested lexemes (reduplicated perfects of the aamanaffed type, giving $f$-perfects), analogical reshapings (taking over the $-f$-from the reduplicated perfect fufens and introducing it elsewhere, the same with the -tt-perfect) and univerbation (the $n k y$ perfect) of the type postulated by Rix. Yet problems with that solution are also numerous. For one, analogy is very difficult to prove. Univerbations do occur in Latin and Sabellic but we do not have a single uncontracted form to prove our point of the periphrasis, other than the typical Latin elided perfect passives or the Sabellic forms like teremnatust.

However, I think that our main problem is that the material at our disposal is relatively small and incomplete. Therefore there is always the chance that the key to our mystery is still buried somewhere in the grounds of the hidden past of ancient Italy, waiting to be unearthed. 


\section{APPENDIX}

\section{LIST OF THE ATTESTED FORMATIONS OF THE PERFECT IN THE SABELLIC LANGUAGES}

Following is the alphabetical list of the attested formations of the perfect in the Sabellic languages (listed as evidenced in WOU). Compounded forms are marked with a hyphen between the preverb and the verbal stem. Question marks indicate dubious forms or interpretations. The glosses normally indicate the number of the inscription in the handbook of Emil Vetter (1953, abbreviated as Ve.); sometimes, if the inscription was found later, in its supplement by Paolo Poccetti (1979, abbreviated as Pocc.); and always in the newest edition of the texts by Helmut Rix (2002, all the other abbreviations). Umbrian forms are glossed with the number of the Iguvine table they are found on (i.e. IIb is the second table, side " $b$ " and VIIa is the seventh table, side "a", etc.).

\begin{tabular}{|c|c|c|c|}
\hline Form & Language & Person \& Tense & Gloss \\
\hline afted & Paelignian & 3 sg. pf. & Ve. 213,6 / Pg 9 \\
\hline aflakus & Oscan & 2 sg. fut. II & Ve. 6,10,11 / Cp 37 \\
\hline$\alpha f \lambda \kappa \varepsilon \iota \tau$ & Oscan & 3 sg. perf. ? & Ve. 183 / Lu 13 \\
\hline aikdafed & Oscan & 3 sg. ind. pf. & Ve. 150 / Sa 7 \\
\hline amatens & Marrucinian & 3 pl. pf. & Ve. $218,11 / \mathrm{MV} 1$ \\
\hline apelus & Umbrian & 3 sg. fut. II & IIb 27 \\
\hline apelust & Umbrian & 3 sg. fut. II & Va 17 \\
\hline angetuzet & Oscan & 3 pl. fut. II & TB 20 \\
\hline angitu[st or [zet & Oscan & 3 sg. or pl. fut II. & TB 2 \\
\hline anter.vakaze & Umbrian & 3 sg. subj. perf. pass.? & Ib 8 \\
\hline ander.uacose & Umbrian & 3 sg. subj. perf. pass.? & VI b 47 \\
\hline atahus & Volscian & 3 sg. fut. II & Ve. 222,1 VM 2 \\
\hline benus & Umbrian & 2 or 3 sg. fut. II & IIb 16 \\
\hline benust & Umbrian & 3 sg. fut II & VIb 53 \\
\hline benurent & Umbrian & 3 pl. fut. II & Va 25, 28, Vb 5 \\
\hline benurent & Umbrian & 3 pl. fut. II & VIb 57 \\
\hline benuso & Umbrian & 3 pl. fut. II & VIb 64, 65 VIIa 2 \\
\hline kúm-bened & Oscan & 3 sg. pf. & CA A 10 \\
\hline ce-bnust & Oscan & 3 sg. fut. II & TB 20 \\
\hline dadíkatted & Oscan & 3 sg. pf. & Ve. 151 / Pocc. 19 / Sa 21 \\
\hline
\end{tabular}




\begin{tabular}{|c|c|c|c|}
\hline Form & Language & Person \& Tense & Gloss \\
\hline dersicust & Umbrian & 3 sg. fut. II & VIb 63 \\
\hline dersicurent & Umbrian & 3 pl. fut. II & VIb 62 \\
\hline deded & Oscan & 3 sg. pf. & $\begin{array}{l}\text { Ve. } 11 \text { (two times) / Po } 3 \\
\text { Ve } 13,19 \text { / Po } 5,10 \\
\text { Ve } 140 \text { / Sa } 22 \\
\text { Ve } 153 \text { / Sa } 5\end{array}$ \\
\hline de]ded & Oscan & 3 sg. pf. & Ve 152 / Sa 3 \\
\hline$\delta \varepsilon \delta \varepsilon \tau$ & Oscan & 3 sg. pf. & Ve $191 /$ Lu 19 \\
\hline ded. & Marsian & 3 sg. pf. & Ve 223 / VM 3 \\
\hline tetet & Pre-Samnite & 3 sg. pf. & Ve. 101 / Ps 3 \\
\hline dede & Umbrian & 3 sg. pf. & Ve 230 / Um 11 \\
\hline dedens & Oscan & 3 pl.pf. & $\begin{array}{l}\text { Ve } 108 \text { / Pocc } 132 \text { / Cm } 9 \\
\text { Pocc } 133 / \mathrm{Cm} 4 \\
\text { Cm } 2\end{array}$ \\
\hline $\operatorname{ded}[\mathrm{ens}$ & Oscan & 3 pl. pf. & Pocc. 16 / Sa 24 \\
\hline$\delta \varepsilon \delta \varepsilon v \varsigma$ & Oscan & 3 pl. pf. & Pocc. 148 / Lu 2 \\
\hline teřust & Umbrian & 3 sg. fut. II & Ib 34 \\
\hline dirsust & Umbrian & 3 sg. fut. II & VIIa 43 \\
\hline dadid & Oscan & 3 sg. subj. pf. & Ve. 6,4 \\
\hline a-teřafust & Umbrian & 3 sg. fut. II & $\mathrm{Ib} 40$ \\
\hline an-dersafust & Umbrian & 3 sg. fut. II & VIIb 3 \\
\hline an-dirsafust & Umbrian & 3 sg. fut. II & VIIa 46 \\
\hline disleralinsust & Umbrian & 3 sg. fut. II & VIa 7 \\
\hline duunated & Oscan & 3 sg. pf. & Ve. 149,8 / Sa 4 \\
\hline ehpeílatasset & Oscan & 3 pl. pf. pass. & Ve. 81 / Cp 24 \\
\hline eiscurent & Umbrian & 3 pl. fut. II & Vb 10,15 \\
\hline iust & Umbrian & 3 sg. fut. II & VIa 7 \\
\hline am-pre-fu $<\mathbf{u}>\mathbf{s}$ & Umbrian & 3 sg. fut. II & Ib 20 \\
\hline am-bre-furent & Umbrian & 3 pl. fut. II & VIb 56 \\
\hline da-etom est & Umbrian & 3 sg. perf. pass. & VIa 28,37,47, VIb 30 \\
\hline per-etom est & Umbrian & 3 sg. perf. pass. & VIa 27,37,47, VIb 30 \\
\hline eitipes & Umbrian & 3 pl.pf. & Va 2,14 \\
\hline
\end{tabular}




\begin{tabular}{|c|c|c|c|}
\hline Form & Language & Person \& Tense & Gloss \\
\hline emps (est) & Umbrian & 3 sg. pf. pass. & Ve. 236 / Um 6 \\
\hline emmens & Oscan & 3 pl. pf. act. & Pocc. 134 / Cm 5 \\
\hline per-emust & Oscan & 3 sg. fut. II & TB 15 \\
\hline pert-emust & Oscan & 3 sg. fut. II & TB 4 \\
\hline fufens & Oscan & 3 pl. pf. & Ve. 84, 85 / Cp. 29, 30 \\
\hline$f \varepsilon f ı \kappa \varepsilon \delta$ & Pre-Samnite & & Ps 20 \\
\hline $\mathrm{fuff}_{\mathrm{F}} \delta$ & Pre-Samnite & & Ps 20 \\
\hline fufuFo $\delta$ & Pre-Samnite & & Ps 20 \\
\hline fuid & Oscan & 3 sg. subj. pf. & TB 28,29 \\
\hline fust & Oscan & 3 sg. fut. II & $\begin{array}{l}\text { TB 19-30 (6 times), TB Pocc. } \\
185,8\end{array}$ \\
\hline fust & Umbrian & 3 sg. fut. II & Ib 7,39 III 6 Va 4,11,19,20 \\
\hline fust & Umbrian & 3 sg. fut. II & $\begin{array}{l}\text { VIa } 7, \text { VIb } 39,41,42,47 \text { (two } \\
\text { times), VIIa } 45 \text {, VIIb } 1\end{array}$ \\
\hline fus & Umbrian & 3 sg. fut. II & VIb 40 \\
\hline furent & Umbrian & 3 pl. fut. II & Va 22 \\
\hline fefure & Umbrian & 3 pl. fut. II & IIa 4 \\
\hline ad-fust & Oscan & 3 sg. fut. II & Ve. 86 / Cp 31 \\
\hline (ad)fust & Oscan & 3 sg. fut. II & Ve. 87 / Cp 32 \\
\hline famatted & Oscan & 3 sg. pf. & Ve. 163 / Hi 1 \\
\hline faamated & Oscan & 3 sg. pf. & Ve. 154 / Pocc. 18 / Sa 13 \\
\hline$\alpha-f \alpha \alpha \mu \alpha \tau \varepsilon \delta$ & Oscan & 3 sg. pf. & Pocc. 167 / Lu 6 \\
\hline$\alpha-f \alpha \alpha \mu \alpha[$ & Oscan & 3 sg. pf. & Pocc. 168 / Lu 7 \\
\hline$\alpha-f a \mu \alpha \tau \varepsilon \delta / \tau$ & Oscan & 3 sg. pf. & Pocc. 175,6 / Lu 5 \\
\hline$a \tau-f a \mu \alpha \tau \tau \varepsilon \nu \varsigma$ & Oscan & 3 pl. pf. & Pocc. 150 / Lu 3 \\
\hline$f e<f>$ acid & Oscan & 3 sg. subj. pf. & TB 10 \\
\hline fefacust & Oscan & 3 sg. fut. II & TВ 11,17 \\
\hline fecront & Marsian & 3 pl.pf. & Pocc. 223 \\
\hline fec $(e d ?)$ & Marrucinian & 3 pl.pf. & Pocc. 206 / MV 3 \\
\hline face & Umbrian & 3 sg. pf. & Um 3 \\
\hline fakust & Umbrian & 3 sg. fut. II & IV 31 \\
\hline
\end{tabular}




\begin{tabular}{|c|c|c|c|}
\hline Form & Language & Person \& Tense & Gloss \\
\hline fakurent & Umbrian & 3 pl. fut. II & Ib 34 \\
\hline facurent & Umbrian & 3 pl. fut. II & VII 43 \\
\hline$\alpha \vee a-f a k \varepsilon \tau$ & Oscan & 3 sg. pf. & Ve. 190 / Lu 18 \\
\hline fifikus & Oscan & 2 sg. fut. II & Ve. 6,5 / Cp 37 \\
\hline fi]r[i]mens & Oscan & 3 pl.pf. & Ve. $9+10 /$ Po 2 \\
\hline frosetom est & Umbrian & 3 sg. pf. pass. & VIa 28, 37, 47 VIb 303 \\
\hline habus & Umbrian & 3 sg. fut. II & VIb 40 \\
\hline haburent & Umbrian & 3 pl. fut. II & VIIa 52 \\
\hline hipid & Oscan & 3 sg. subj. pf. & ТВ $8,14,17$ \\
\hline hipust & Oscan & 3 sg. fut. II & TB 11, ТВ Pocc. 185,8 \\
\hline pru-hipid & Oscan & 3 sg. subj. pf. & TB 25 \\
\hline pru-hipust & Oscan & 3 sg. fut. II & TB 26 \\
\hline iocatin & Paelignian & 3 pl.pf. & Ve. 212 / Pg 1 \\
\hline pro-canurent & Umbrian & 3 pl. fut. II & VIa 16 \\
\hline kellaked & Oscan & 3 sg. pf. & Pocc. 14,15 / Sa 10,12 \\
\hline censas fust & Oscan & 3 sg. fut. II pass. & TB Pocc. 185,8 \\
\hline şersnatur furent & Umbrian & 3 pl. fut. II pass. & Va 22 \\
\hline clisuist & Paelignian & 3 sg. pf. pass. f. & Ve. 213,4 / Pg 9 \\
\hline coisatens & Paelignian & 3 pl.pf. & Ve. 216 / Pg 2 \\
\hline kuratu eru & Umbrian & inf. pf. pass. & Va 26,29 \\
\hline combifianşi & Umbrian & 3 sg. subj. pf. & VIb 52 \\
\hline combifianşiust & Umbrian & 3 sg. fut. II & VIb 49 \\
\hline combifianşust & Umbrian & 3 sg. fut. II & VIIa 5 \\
\hline combifiansiust & Umbrian & 3 sg. fut. II & VIb 52 \\
\hline$\lambda$ ıокакеıт & Oscan & $?$ & Ve. 184,5 / Lu 39 \\
\hline manafum & Oscan & 1 sg. pf. & Ve. 6,3 \\
\hline ma]nafum & Oscan & 1 sg. pf. & Ve. 6,1 / Cp 37 \\
\hline aa-manaffed & Oscan & 3. sg. pf. & Ve. $12,14,15,17$ / Po. $4,6,7,9$ \\
\hline aa-man[aff]ed & Oscan & 3 sg. pf. & Ve. 18 / Po. 14 \\
\hline aa-manafed & Oscan & 3 sg. pf. & Pocc. 34 / Sa 2, Pocc. 20 / Sa 9 \\
\hline
\end{tabular}




\begin{tabular}{|c|c|c|c|}
\hline Form & Language & Person \& Tense & Gloss \\
\hline a]-manafed & Oscan & 3 sg. pf. & Pocc. 15 / Sa 12 \\
\hline a-m[a]nafed & Oscan & 3 sg. pf. & Pocc. 13 / Sa 11 \\
\hline aa- $[\mathrm{m}]$ ana $[\mathrm{ff}] \mathrm{e}[\mathrm{d}$ & Oscan & 3 sg. pf. & Pocc. 17 / Sa 8 \\
\hline e-manafed & Oscan & 3 sg. pf. & Pocc. 14 / Sa 10 \\
\hline pepurkurent & Umbrian & 3 pl. fut. II & $\mathrm{Vb} 5$ \\
\hline com-parascuster & Oscan & 3 sg. fut. II pass. & TB 4 \\
\hline persnis fust & Umbrian & 3 sg. fut. II & VIb 39 \\
\hline pesnis fus $(t)$ & Umbrian & 3 sg. fut. II & VIb 40,41 \\
\hline peperscust & Umbrian & 3 sg. fut. II & VIb 5 \\
\hline pepescus & Umbrian & 3 sg. fut. II & VIIa 8 \\
\hline pesetom est & Umbrian & 3 sg. pf. pass. & VIa 27,37,47, VIb 30 \\
\hline pperci & Paelignian & 3 sg. pf. & Ve. 203 / Pg 4 \\
\hline prúfatted & Oscan & 3 sg. pf. & $\begin{array}{l}\text { Ve. } 11,14 \text { / Po } 3,6 \\
\text { Ve } 152,153 \text { / Sa } 3,5 \\
\text { Pocc. } 13,14,15 \text { / Sa } 11,10,12\end{array}$ \\
\hline prúfatte $[d$ & Oscan & 3 sg. pf. & $\mathrm{Cm} 3$ \\
\hline prúfated & Oscan & 3 sg. pf. & Pocc. 20 / Sa 9 \\
\hline$\pi \rho \circ f \alpha \varepsilon \delta$ & Oscan & 3 sg. pf. & Pocc. 175, 7 / Lu 5 \\
\hline prúfatt(e)d & Oscan & 3 sg. pf. & Ve. 13 / Po 5 \\
\hline prúf]atted & Oscan & 3 sg. pf. & Ve. 19 / Po 10 \\
\hline pr[ú]fated & Oscan & 3 sg. pf. & Pocc. 34 / Sa 2 \\
\hline prúfattens & Oscan & 3 pl.pf. & Ve. 8 / Po. 1, Cm 2 \\
\hline p]rúfatt[ens & Oscan & 3 pl.pf. & Ve. 143 / Sa 14 \\
\hline prúffed & Oscan & 3 sg. pf. & $\begin{array}{l}\text { Ve. } 107 \text { / Cm } 10 \\
\text { Ve. } 156 \text { / Sa } 25\end{array}$ \\
\hline prúftúset & Oscan & 3 pl. pf. pass. n. & CA A 16 \\
\hline prúftas sú[nt & Oscan & 3 pl. pf. pass. f. & Ve. 141 / Sa 17 \\
\hline pru-sikurent & Umbrian & 3 pl. fut. II & Va 26,28 \\
\hline purtiius & Umbrian & 3 sg. fut. II & Ia 27,30 , IIa 7,9 \\
\hline purtitius & Umbrian & 3 sg. fut. II & Ia 33 \\
\hline purtinşus & Umbrian & 3 sg. fut. II & Ib 33 \\
\hline
\end{tabular}




\begin{tabular}{|c|c|c|c|}
\hline Form & Language & Person \& Tense & Gloss \\
\hline purdinşiust & Umbrian & 3 sg. fut. II & VIIa 43 \\
\hline purdinşus & Umbrian & 3 sg. fut. II & VIb $23,37,38$ \\
\hline purdinsust & Umbrian & 3 sg. fut. II & VIb 16,24 \\
\hline purditom fust & Umbrian & 3 sg. fut. II pass. & VIIa 45 \\
\hline purdito fust & Umbrian & 3 sg. fut. II pass. & VIb 42 \\
\hline purtitu fust & Umbrian & 3 sg. fut. II pass. & Ib 39, Va 18 \\
\hline portust & Umbrian & 3 sg. fut. II & VIIb 3 \\
\hline seganatted & Oscan & 3 sg. pf. & Pocc. 21 / Sa 35 \\
\hline sistiatiens & Volscian & 3 pl. pf. & Ve. 222,4 / VM 2 \\
\hline sesust & Umbrian & 3 sg. fut. II & VIa 5 \\
\hline ander-sesus $<t>$ & Umbrian & 3 sg. fut. II & VIa 7 \\
\hline spa $<$ t $>$ u fust & Umbrian & 3 sg. fut. II pass. & Va 20 \\
\hline staflatasset & Oscan & 3 pl. pf. pass. & Ve. 81 / Cp 24 \\
\hline staieffud & Oscan & 3 sg. pf. ? & Ve. 86 / Cp 31 \\
\hline ad-staíúh & South Picene & 3 pl. pf.? & AP 2 \\
\hline pra]istaiúh & South Picene & 3 pl. pf.? & RI 1 \\
\hline stakaz est & Umbrian & 3 sg. pf. pass. & IIa 15 \\
\hline subator sent & Umbrian & 3 pl. pf. pass. & VIa 27,36,46, VIb 29 \\
\hline entelust & Umbrian & 3 sg. fut. II & VIb 50 \\
\hline entelus & Umbrian & 3 sg. fut. II & Ib 12 \\
\hline teremnattens & Oscan & 3 pl. pf. & Ve. $8,5-6$ \\
\hline teremna $[t]$ tens & Oscan & 3 pl. pf. & Ve. $8,2-3 /$ Po 1 \\
\hline teremnattens & Oscan & 3 pl. pf. & Ve. 9+10 / Po 2 \\
\hline teremnatust & Oscan & 3 sg. pf. pass. & Ve. 8,4 / Po 1 \\
\hline termnas (est) & Umbrian & 3 sg. pf. pass. & Ve. 236 / Um 6 \\
\hline tríbarakat.tíns & Oscan & 3 pl. pf. subj. & CA B 22 \\
\hline tríbarakat.tuset & Oscan & 3 pl. fut. II & CA B 13,16 \\
\hline tuderato est & Umbrian & 3 sg. pf. pass. n. & VIa 8 \\
\hline úpsed & Oscan & 3 sg. pf. & Pocc. 34 / Sa 2 \\
\hline
\end{tabular}




\begin{tabular}{|c|c|c|c|}
\hline Form & Language & Person \& Tense & Gloss \\
\hline upsed & Oscan & 3 sg. pf. & $\begin{array}{l}\text { Ve. } 142 \text { / Sa 18, Ve. } 177 \\
\text { Pocc. } 56 \text { / Sa } 33\end{array}$ \\
\hline ups(e)d & Oscan & 3 sg. pf. & Sa 34 \\
\hline upse[d & Oscan & 3 sg. pf. & Hi 8 \\
\hline ups(ed) & Oscan & 3 sg. pf. & Ve. 176 / Sa 32 \\
\hline opsút & South Picene & 3 sg. pf. & AQ 2 \\
\hline o]psúq & South Picene & 3 sg. pf. & TE 7 \\
\hline uupsens & Oscan & 3 pl. pf. & Ve. 8 / Po. 1 \\
\hline upsens & Oscan & 3 pl. pf. & Ve. 16 / Po. 8 \\
\hline 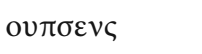 & Oscan & 3 pl.pf. & Ve. 196 / Me 1,3 \\
\hline oşens & Vestinian & 3 pl. pf. & Pocc. 207 / MV 2 \\
\hline opset (a est) & Umbrian & 3 sg. pf. pass. & Ve. 234 / Um 7 \\
\hline oseto $(e s t)$ & Umbrian & 3 sg. pf. pass. & Ve. 233 / Um 8 \\
\hline upsatuh sent & Oscan & 3 pl. pf. pass. & Ve. $124 a-c / S i ~ 4-6$ \\
\hline ortom est & Umbrian & 3 sg. pf. & VIa 46 \\
\hline orto est & Umbrian & 3 sg. pf. & VIa 26,36, VIb 29 \\
\hline urtu fefure & Umbrian & 3 sg. fut. II ? & IIa 4 \\
\hline urust & Oscan & 3 sg. fut. II & TB 14,16 \\
\hline usaşe & Umbrian & 3 sg. pf. ? & IIa 44 \\
\hline usaie & Umbrian & 3 sg. pf. ? & Ib 45 \\
\hline uaśetom est & Umbrian & 3 sg. pf. pass. & VIa 37 \\
\hline uasetom est & Umbrian & 3 sg. pf. pass. & VIa 47, VIb 30 \\
\hline uaseto est & Umbrian & 3 sg. pf. pass. & VIa 27 \\
\hline uesticos (fust) & Umbrian & 3 sg. fut. II pass. & VIb 25 \\
\hline vurtus & Umbrian & 3 sg. fut. II & IIa 2 \\
\hline kuvurtus & Umbrian & 3 sg. fut. II & Ib 11 \\
\hline couortus & Umbrian & 3 sg. fut. II & VIIa 39 \\
\hline courtust & Umbrian & 3 sg. fut. II & VIa 6 \\
\hline couortuso & Umbrian & 3 sg. fut. II pass. & VIb 64 \\
\hline
\end{tabular}




\section{List of abbreviations}

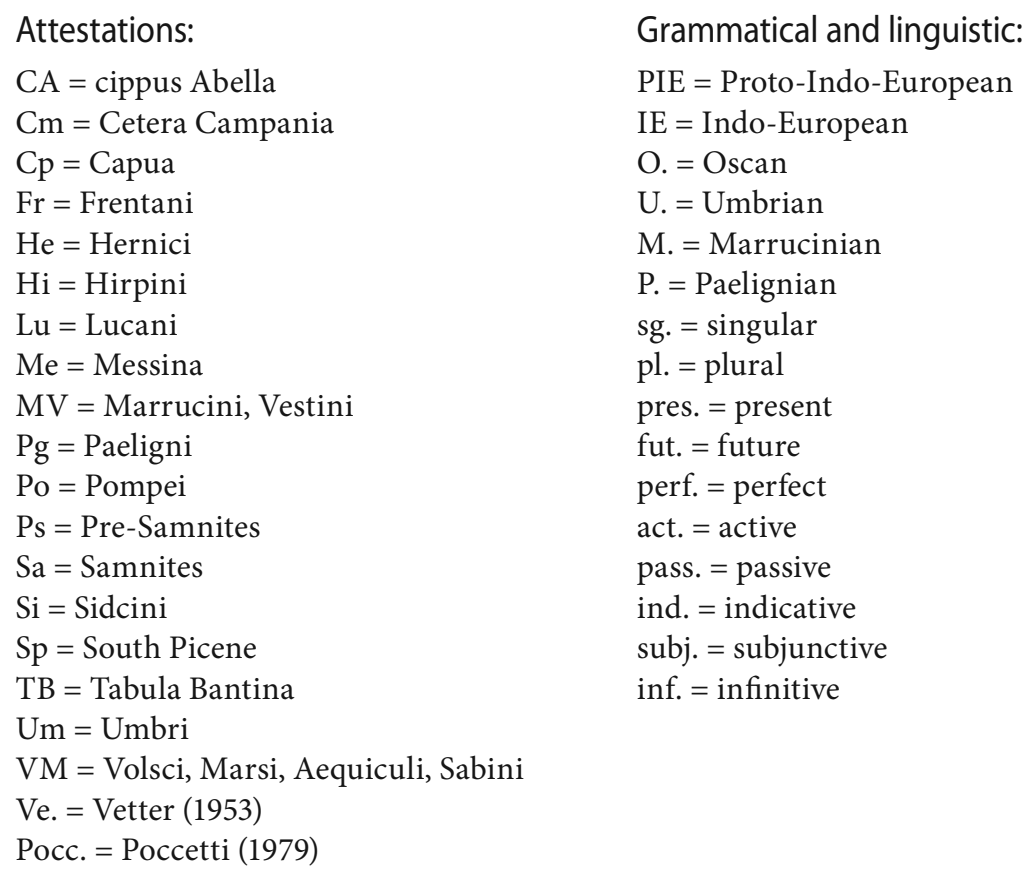

As is common in scientific literature, Sabellic forms written in native alphabets are printed in bold, those written in the Latin alphabet in cursive and those in the Greek alphabet in Greek.

\section{Bibliography}

Adiego Lajara I. 1992. Protosabelio, osco-umbro, sudpiceno. Barcelona.

Beckwith M. 2005. Volscian sistiatiens and the Oscan - tt- perfect. - Historische Sprachforschung 118: 145-159.

Beckwith M. 2006. The old Italic $\bar{o}$-perfect and the Tortora inscription. [Abstract from the $18^{\text {th }}$ annual UCLA Indo-European conference. Los Angeles 03.11-04.11.2006]. Los Angeles.

Beckwith M. 2008. The Latin imperfect and $v$-perfect: A paradigm split. [Abstract from the $20^{\text {th }}$ annual UCLA Indo-European conference. Los Angeles 31.10-01.11.2008]. Los Angeles.

Brugmann K. 1893. Grundriss der vergleichenden Grammatik der indogermanischen Sprachen. [Dritter Band]. Strassburg.

Buck C.D. 1904. A grammar of Oscan and Umbrian. Boston.

Burrow T. 2001. The Sanskrit language. Delhi.

Clackson J. 2007. Indo-European linguistics. An introduction. Cambridge.

Cowgill W.C. 1957. Indo-European long-vowel preterits. [Unpublished Ph.D. dissertation. Yale University]. New Haven.

Cowgill W.C. 1973. The source of Latin stāre, with notes on comparable forms elsewhere in Indo-European. - The Journal of Indo-European Studies 1.3: 271-303. 
Diels P. 1959. Zur umbrischen Konjugation. - Münchener Studien zur Sprachwissenschaft 15: $17-22$.

Fortson B.W. 2004. Indo-European language and culture. An introduction. Oxford.

Hamp E.P. 1990. On the Oscan-Umbrian $f$-perfect. - Glotta 68: 211-215.

Xodorkovskaya V.V. 1993. K predystorii sistemy vremen infekta / perfekta v latinskom i osksko-umbrskom yazykax. - Voprosy yazykoznaniya 1993.2: 58-68

Hoffmann K. 1970. Das Kategoriensystem des indogermanischen Verbums. - Münchener Studien zur Sprachwissenschaft 28: 19-41.

Jasanoff J. 1987. The tenses of the Latin perfect system. - Cardona G., Zide N.H. (eds.) Festschrift for Henry Hoenigswald on the occasion of his seventieth birthday. Tübingen: 177-183.

Jasanoff J. 1991. The origin of the Italic imperfect subjunctive. - Historische Sprachforschung 104: 84-105.

Jasanoff J. 2003. Hittite and the Indo-European verb. Oxford.

Jerrett D.H. 1974. The Umbrian -nky- perfect. - Transactions of the American Philological Association 104: 169-178.

Kronasser H. 1956. Historische Laut- und Formenlehre des Hethitischen. Heidelberg.

Kümmel M.J. 2007. Grundzüge der historischen lateinischen Sprachwissenschaft. [Skriptum. Sprachwissenschaftliches Seminar der Albert-Ludwigs-Universitat]. Freiburg.

LIV $^{2} 2001=$ Rix H. et al. (eds.) 2001. Lexikon der indogermanischen Verben. Wiesbaden.

Markey T.L. 1985. Some Italic perfects revisited. - Word 6: 26-41.

Meiser G. 1986. Lautgeschichte der umbrischen Sprache. Innsbruck.

Meiser G. 2003. Veni vidi vici. Die Vorgeschichte der lateinischen Perfektsystems. München.

Olzscha K. 1958. Das umbrische Perfekt auf -nki. - Glotta 36: 300-304.

Olzscha K. 1963. Das f-Perfektum im Oskisch-Umbrischen. - Glotta 41: 290-299.

Osthoff H. 1884. Zur Geschichte des Perfects im Indogermanischen. Strassburg.

Pike M. 2003. The Indo-European long-vowel preterite: New Latin evidence. [Paper presented at the International Conference on Historical Linguistics. 14 August 2003, Copenhagen]. Copenhagen.

von Planta R. 1892-1897. Grammatik der oskisch-umbrischen Dialekte. [2 vols]. Strassburg. Poccetti P. 1979. Nuovi documenti italici. Pisa.

Poultney J.W. 1959. The bronze tables of Iguvium. Baltimore.

Pulgram E. 1978. Italic, Latin, Italian. Heidelberg.

Ringe D. 1984. The perfect tenses in Greek inscriptions. [Unpublished Ph.D. dissertation. Yale University]. New Haven.

Ringe D. 1990. The Tocharian active s-preterite: A classical sigmatic aorist. - Münchener Studien zur Sprachwissenschaft 51: 183-242.

Ringe D. 1996. On the chronology of sound changes in Tocharian. [vol. 1]. New Haven.

Ringe D. 2006. A linguistic history of English. [vol. 1]. Oxford.

Rix H. 1992. Zur Entstehung des lateinischen Perfektparadigmas. - Panagl O., Krisch T. (eds.) Latein und Indogermanisch. [Akten des Kolloquiums der Indogermanischen Gesellschaft, Salzburg, 23.-26.09.1986]. Innsbruck: 221-240.

Rix H. 2002. Sabellische Texte. Heidelberg.

Rix H. 2003a. Towards a reconstruction of Proto-Italic: the verbal system. - Huld M. et al. (eds.) Journal of Indo-European Studies Monograph 47: 1-24.

Rix H. 2003b. Ausgliederung und Aufgliederung der italischen Sprachen. - Bammesberger A., Vennemann T. (eds.) Languages in prehistoric Europe. Heidelberg: 147-172.

Safarewicz J. 1953. Zarys gramatyki historycznej języka łacińskiego. Fonetyka historyczna ifleksja. Warszawa. 
Safarewicz J. 1967. Studia językoznawcze. Warszawa.

Saint John J. 1973a. The perfect in Oscan and Umbrian. - Canadian Journal of Linguistics 18: $1-6$.

Saint John J. 1973b. The Oscan-Umbrian future perfect in -us-. - Orbis 22: 155-160.

Schultze W. 1887. Das lateinische v-perfectum. - Zeitschrift für vergleichende Sprachforschung 28: 266-274.

Seldeslachts H. 2001. Études de morphologie historique du verbe latin et indo-européen. Louvain.

Silvestri D. 1998. The Italic languages. - Ramat A., Ramat P. (eds.) Indo-European languages. London, New York: 322-344.

Sommer F. 1926. Oskisch-Umbrisches. - Indogermanische Forschungen 43: 40-46.

Sowa W. 1998. Notes on the Mycenaean verbal morphology: The finite verb forms. - Linguistica Baltica 7: 271-297.

van der Staaij R.J. 1995. A reconstruction of Proto-Italic. [Unpublished Ph.D. dissertation. Universiteit Leiden]. Leiden.

Tichy E. 2004. Indogermanistisches Grundwissen. Bremen.

Untermann J. 2002. Das Perfekt der Sekundärverben im Oskisch-Umbrischen. - Fritz M., Zeilfelder S. (eds.) Novalis Indogermanica: Festschrift für Günter Neumann zum 80. Geburtstag. Graz: 489-495.

De Vaan M. 2008. Etymological dictionary of Latin and the other Italic languages. Leiden. Vetter E. 1953. Handbuch der italischen Dialekte. Heidelberg.

Wallace R. 1985. Volscian sistiatiens. - Glotta 63: 93-101.

Wallace R. 2007. The Sabellic languages of ancient Italy. München.

WOU $2000=$ Untermann J. 2000. Wörterbuch des Oskisch-Umbrischen. Heidelberg. 